University of South Carolina

Scholar Commons

$9-2004$

\title{
This Land Is Our Land: Immigrants and Power in Miami
}

Jimy M. Sanders

University of South Carolina - Columbia, jimsand@sc.edu

Follow this and additional works at: https://scholarcommons.sc.edu/socy_facpub

Part of the Sociology Commons

\section{Publication Info}

American Journal of Sociology, Volume 110, Issue 2, 2004, pages 529-531.

This Book Review is brought to you by the Sociology, Department of at Scholar Commons. It has been accepted for inclusion in Faculty Publications by an authorized administrator of Scholar Commons. For more information, please contact digres@mailbox.sc.edu. 
identity while highlighting its rootedness in economic, political, and social materialities, more so than in originary cultural claims. The link of authenticity provided by Senegalese traders to an imagined monolithic Africa is the cornerstone of the latter's diasporic organization despite its stereotypical support of images of "Africans" as exotic and its denial of their cultural specificity. Ghanaian women and Congolese youth eschew claims of return even while maintaining and sustaining their diasporic identities.

There is a significant problem with almost all of the book's contributions in their lack of specification as to what constitutes the boundaries of a diasporic community. The highly localized case studies prevent engagement with this broader issue. What may be unique about diaspora is its organization across multiple locations of "open" and "unbounded" spaces despite its dependence on putative claims to an originary "homeland." The volume allows little room for examination of this possibility. Nonetheless, it makes a significant contribution to the conceptualization of diaspora and, indirectly, to its theorization.

This Land Is Our Land: Immigrants and Power in Miami. By Alex Stepick, Guillermo Grenier, Max Castro, and Marvin Dunn. Berkeley: University of California Press, 2003. Pp. viii +192.

Jimy M. Sanders

University of South Carolina

The goal of This Land Is Our Land is to improve our understanding of how immigrants are influenced by the host society and how the host society is influenced by immigrants. Consequently, the book conforms to most current research on immigration in that it is sensitive to the nonrecursive relationship involving host-guest accommodation. Interpersonal interaction across the lines of nativity, race, and ethnicity is seen as the most important "fulcrum" (p. 26) that tips the actions of groups toward, or away from, developing accommodating relationships with outsiders. In order to explicate the role of interpersonal interaction in moving groups toward, or away from, accommodation, the authors focus on the relative power of groups, the social context within which interaction takes place, and the diversity of the actors involved.

The study takes place in Miami and focuses on three social arenas: business and commerce, schools, and workplaces. For the most part, the data were collected 15 years ago. The methodological approach combines participant observation and interviewing. Civic elites and leaders of the business community were interviewed. Interviewees included AfricanAmericans, non-Hispanic white natives (hereafter "whites"), and Latinos. One high school, attended by large numbers of Haitians and AfricanAmericans, was studied. Participant observation and interviewing were 
American Journal of Sociology

carried out in this part of the study. The places of work examined included two hotels, an apparel plant, a construction site, and a union hall. This part of the study also included participant observation and interviewing. The book has a methodological appendix.

The main body of the book is approximately 150 pages and includes five chapters. Chapter 1 seems to be directed toward undergraduates. It states the main thesis of the researchers, but otherwise the chapter glosses over the history of immigration and nativism in the United States, early theoretical arguments pertaining to immigration from Europe, and the unique character of Miami. Chapter 2 presents the analysis of civic and business elites. Relying on 17 interviews of male leaders in Miami, the authors do an excellent job in describing how the relative power-mostly economic and political-of Cubans, whites, and African-Americans influences the nature and extent of accommodations worked out between the groups. The chapter gives the reader a good sense of how change over time in the relative power of Cubans and whites pushed the latter toward accommodating the former. With the ascent of Cuban power, white leaders had to change. Cuban elites, too, slowly moved toward making accommodations important to white leaders. But finding common ground is always a test. In discussing the Elián Gonzalez affair of 1999-2000, the authors show how contemporary Miami can quickly become divided along racial, ethnic, and nativity lines that make mutually accommodating action difficult. Much of chapter 2 describes the disadvantaged position of African-Americans. As a group, African-Americans do not have the power to compete with whites or with Cubans. Although white leaders appear to have been more active than Cuban leaders in reaching out to AfricanAmericans, little effective action has transpired.

Chapter 3 is most effective in demonstrating how interpersonal interactions taking place at work affect the willingness of members of one group to make accommodations to members of another group. The workers examined are in blue-collar or low-end service occupations. This chapter paints a bleak picture-conflicts intrinsic to the nature of the work are usually interpreted by the participants as being motivated by nativist or racist sentiments. The elites studied in chapter 2 are much more likely than the workers examined in chapter 3 to see the difficulties associated with interethnic relations as manageable. Chapter 4 describes how the perceived cultural advantages of native-born African-American high school students give them power over Haitian students. The result is that many Haitians appear to assimilate into "inner-city African American youth culture" (p. 115). But the authors find that once Haitian students demonstrate that their identity includes being an African-American, they become more empowered to also assert their Haitian identity. Haitians who are elites in the student body (e.g., outstanding scholars or athletes) have the most power with which to openly demonstrate their Haitian identity.

The closing chapter summarizes the authors' arguments, their findings, 
and how their work fits into the literature. At one point they argue that they offer a different perspective in the study of how power affects interethnic relations. But this difference is not attributable to a new theoretical insight regarding the role of power in interethnic relations. Rather, the authors attribute this difference to two of their findings: (1) immigrants can gain power and overcome initial disadvantages, and (2) group power varies by context. In Miami, where power relations across lines of nativity and ethnicity are often "upside down" (p. 139) because of local demography and the economic resources of Cubans, these findings are indisputable but they are not new and, consequently, they do not add much to the existing body of knowledge. This book is most useful for undergraduates. It does not provide a significant advancement in the study of immigration and interethnic relations.

Slavery in the American Mountain South. By Wilma A. Dunaway. Cambridge: Cambridge University Press, 2003. Pp. 352. \$70.00 (cloth); $\$ 25.00$ (paper).

Art Budros McMaster University

Although antebellum slavery represents a pivotal chapter in U.S. history and Americans continue to deal with its aftereffects, sociologists inexplicably have ceded the analysis of enslavement in the Old South to historians. Written by a sociologist, this book thus is a welcome addition to the literature. Drawing on a large statistical database and extensive archival materials, Wilma Dunaway explores bondage in the mountain South, which spanned 215 counties in nine states disproportionately situated in the upper South. According to the author, the research especially is important because southern Appalachia not only has been underexamined but also has been misrepresented as a region largely devoid of slavery.

With respect to the misrepresentation of servitude, a review of demographic trends among masters and chattels leads to the surprising conclusion that slavery had little presence in about half of southern Appalachia, had a weak hold on about one-quarter of the region, and reached lower South proportions in only about one-quarter of it. Moreover, black bondage was significant only in misclassified or atypical counties: those in Virginia and North Carolina actually were located in the Piedmont region, the home of the states' tobacco-growing plantocracies, and those in Georgia, Alabama, and South Carolina penetrated the Deep South, where masters needed large plantations and unfree labor forces in order to cultivate cotton. While the evidence on plantation size also indicates that slavery largely was absent in the mountain South, evidence on the unequal distribution of power and privilege among whites shows that the 